\title{
Design and Synthesis of a New Tricyclic Scaffold for Molecular Recognition
}

\author{
Juana Robles Caycho ${ }^{\mathrm{a}}$, Fernando García-Tellado ${ }^{\mathrm{a} *}$, Pedro de Armas ${ }^{\mathrm{a} *}$, \\ Jose Juan Marrero-Tellado ${ }^{\mathrm{b}}$

\footnotetext{
${ }^{a}$ Instituto de Productos Naturales y Agrobiología, CSIC, Astrofísico Francisco Sánchez 3, 38206 La Laguna

b Instituto Universitario de Bioorgánica “Antonio González”, Universidad de La Laguna, Astrofísico Francisco Sánchez 2 , 38206 La Laguna, Tenerife, Canary Islands Spain
}

\begin{abstract}
The design of a novel family of tricyclic scaffolds for use in molecular recognition is described. The synthesis of the most simple member of this family is presented and its use exemplified in the synthesis of receptor 2 .
\end{abstract}

The design and synthesis of abiotic receptors for key biological molecules such as peptides, nucleotides or drugs is an active area in the field of supramolecular chemistry. ${ }^{1}$ Because recognition implies geometrical and interactional complementarity between receptor and substrate, factors such as steric complementarity, interactional complementarity, large contact areas and multiple interaction sites have to be taken into account to design a specific receptor for a target substrate(s). ${ }^{2}$ The synthesis of endoreceptors ${ }^{2}$ uses an organic scaffold to create a cavity, cleft or pocket into which the substrate may fit. This cavity is lined with binding sites directed towards the bound species. Ideally, the scaffold should be readily obtained on a multigram scale and easily and selectively incorporated into the designed receptors. With these ideas in mind we have designed the family of organic scaffolds represented in figure 1.

The scaffold presents two well-differentiated domains, the concave one with an imide function to develop

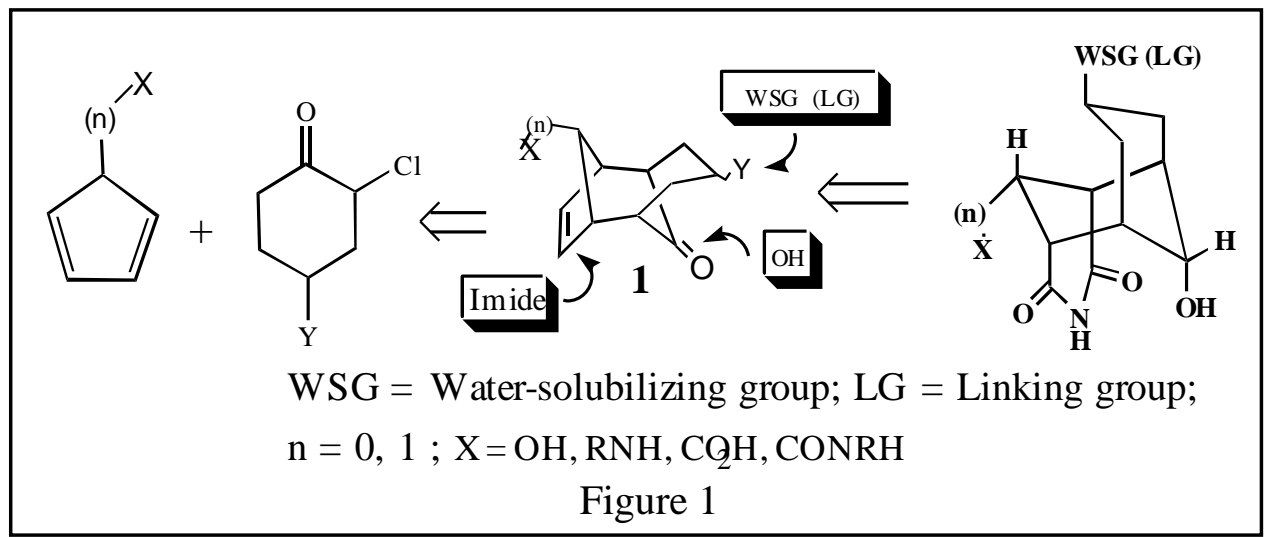
directed H-bonding interactions and two oxygenated groups directed towards the imide and susceptible to be transformed into a variety of molecular recognition motives, and the convex one which posseses a functional group which can be a latent water-solubilizing group, a linking group for the attachment to a solid support, etc. The tricyclic nature of this module makes it conformationally rigid giving a very well-defined three-dimensional architecture with a preorganised functional group array lining the interior of the cavity.

The tricyclic ketone 1 was chosen as a suitable precursor of our scaffold because: a) it can be synthesised by a $[4+3]$ cycloaddition of cyclopentadiene derivatives and functionalized $\alpha$-chloro-cyclohexanones ${ }^{3}$ and $b$ ) it posseses all the functionalites of the scaffold in a masked form (Fig. 1). As a first approach we report here on the synthesis of the receptor $\mathbf{2}$ which incorporates the simplest member of the possible modules and utilises both aryl- stacking and hydrogen-bonding interactions as the binding motives (Scheme 1).

Diastereoselective reduction of ketone $2,{ }^{3}$ protection of the endo-alcohol as the p-methoxybenzoate and ozonolysis afforded the dialdehyde 5 in $60 \%$ yield. Alternatively, oxidation of the benzoate derivative to the 
mixture of $\mathbf{4}$ and 5 followed by periodate oxidation gave the dialdehyde $\mathbf{5}$ in $80 \%$ yield. Pinnick oxidation and dehydration with acetyl chloride afforded the anhydride 6 in 95\% yield. Anhydride opening with ammonia gas and treatment of crude amide-acid with acetyl chloride gave 2 in $84 \%$ yield. ${ }^{4}$

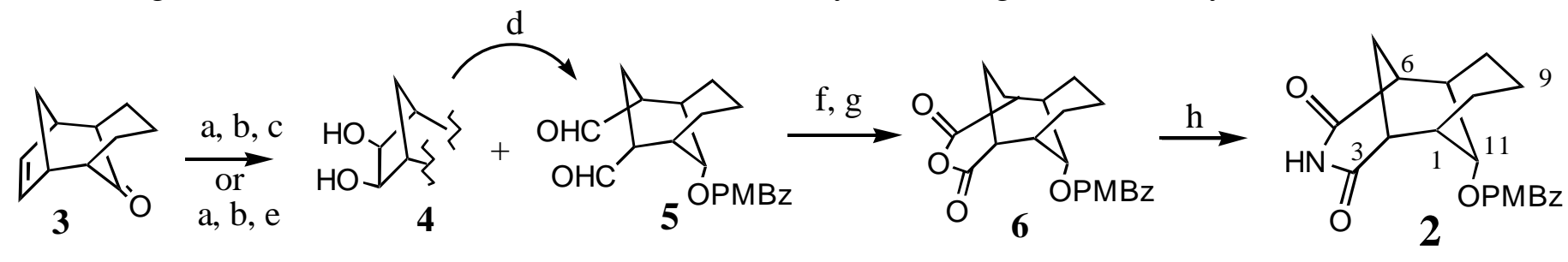

$\mathrm{OPMBz}=\mathrm{p}$-methoxybenzoate

${ }^{\mathrm{a}} \mathrm{LiALH}_{4}$, ether; $0^{\circ} \mathrm{C}$; $\left.\left.{ }^{\mathrm{b}} \mathrm{PMBx}-\mathrm{Cl}, \mathrm{Py}, 60^{\circ} \mathrm{C}, 96 \% ;{ }^{\mathrm{c}} 1\right) \mathrm{KMnO}_{4}, \mathrm{BnNEt}_{3} \mathrm{Cl}, \mathrm{CH}_{2} \mathrm{Cl}_{2}, 0^{\circ} \mathrm{C} ; 2\right) \mathrm{H}_{3} \mathrm{O}^{+}, 80 \%$; ${ }^{d}$ silica gel, $\mathrm{NaIO}_{4}, \mathrm{CH}_{2} \mathrm{Cl}_{2}$, quant.; ${ }^{\mathrm{e}}$ 1) $\mathrm{O}_{3}, \mathrm{CH}_{2} \mathrm{Cl}_{2},-78^{\circ} \mathrm{C}$; 2) $\mathrm{Me}_{2} \mathrm{~S}, 60 \%$; ${ }^{\mathrm{f}}$ aq. $\mathrm{NaClO}_{2}, \mathrm{H}_{2} \mathrm{O}_{2}, \mathrm{MeCN}$, $\mathrm{KH}_{2} \mathrm{PO}_{4}$, quant.; ${ }^{\mathrm{g}} \mathrm{MeCOCl}$, reflux, 95\%; ${ }^{\mathrm{h}}$ 1) $\mathrm{NH}_{3} \mathrm{~g}$, THF, DMAP; 2) $\mathrm{MeCOCl}$, rt, $84 \%$.

\section{Scheme 1}

The receptor behaves similarly to most simple Kemp's triacid-derived receptors used by Rebek to recognise nucleosides. ${ }^{5}$ Thus, when 2-amino-6-picoline was added to a $\mathrm{CDCl}_{3}$ solution of the receptor, measurable complexation-induced shifts in the imide and aromatic protons of 2 were observed. Addition of an excess of 2-amino-picoline resulted in a $1.17 \mathrm{ppm}$ downfield shift of the imide $\mathrm{NH}$ proton resonance together with an upfield shift of the p-methoxy benzoate protons resonance, which are consistent with a complex having the structure shown in figure 2.5
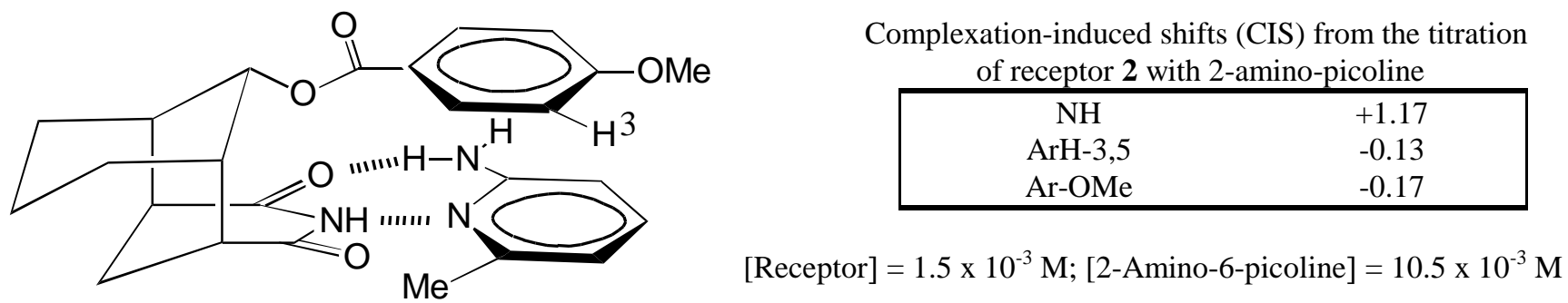

Figure 2

The syntheses of more functionalized and water-soluble modules are in progress.

AcKnowledgement. This work was supported by the Spanish Ministerio de Educación y Ciencia, DGICYT (PB94-0028). JRC thanks the ICI for a predoctoral fellowship.

\section{REFERENCES}

1. For a review of synthetic developments in host-guest chemistry see: J. J. B. Perry and J. D. Kilburn, Contemp. Org. Synth., 1997, 4, 61.

2. J. M. Lehn in Supramolecular Chemistry,Concepts and Perspectives. VCH, New York, 1995.

3. S. Jin, J. Choi, D. Lee, J. K. Cha, J. Am. Chem. Soc., 1995, 117, 10914 and references cited therein.

4. Spectral data: m.p.: $257-258^{\circ} \mathrm{C}$; IR $\left(\mathrm{CHCl}_{3}\right) v_{\max }: 1707$ and $1607 \mathrm{~cm}^{-1} ;{ }^{1} \mathrm{HNMR}\left(\mathrm{CDCl}_{3}\right): 7.83(2 \mathrm{H}, \mathrm{d}, \mathrm{J}=$ $9 \mathrm{~Hz}, \operatorname{ArH}-2,6), 7.61$ (1H, br.s, NH), $6.92(2 \mathrm{H}, \mathrm{d}, \mathrm{J}=9 \mathrm{~Hz}, \mathrm{ArH}-3,5), 5.02$ (1H, br.s, H-11), 3.85 (3H, s, OMe), 2.87 (2H, br.s., H-2,6), 2.73 (1H, dt, J = 14 and $3.2 \mathrm{~Hz}, \mathrm{H}-12$ exo), 2.62(2H, br.s., H-1,7); Anal. Calcd. for $\mathrm{C}_{19} \mathrm{H}_{21} \mathrm{O}_{5} \mathrm{~N}$ : C, 66.46; H, 6.16; N, 4.08. Found: C, 66.34; H, 6.18; N, 4.08.

5. J. Rebek, Jr, Angew. Chem. Int. Ed. Engl., 1990, 29, 245; ibid, Science, 1987, 235, 1478. For other related modules see: D. G. Lonergan, J. Riego and G. Deslongchamps, Tetrahedron Lett., 1996, 37, 6109; D. Mink, G. Deslongchamps, Tetrahedron Lett., 1996, 37 ,7035. 